University of Wollongong

Research Online

Faculty of Social Sciences - Papers (Archive) Faculty of Arts, Social Sciences \& Humanities

2016

Reflections and recommendations for conducting in-depth interviews with people With dementia

\author{
Elizabeth Cridland \\ University of Wollongong, Icridlan@uow.edu.au \\ Lyn Phillipson \\ University of Wollongong, Iphillip@uow.edu.au \\ Christopher R. Brennan-Horley \\ University of Wollongong, chrisbh@uow.edu.au \\ Kate Swaffer \\ University of Wollongong, kswaffer@uow.edu.au
}

Follow this and additional works at: https://ro.uow.edu.au/sspapers

Part of the Education Commons, and the Social and Behavioral Sciences Commons

Research Online is the open access institutional repository for the University of Wollongong. For further information contact the UOW Library: research-pubs@uow.edu.au 


\title{
Reflections and recommendations for conducting in-depth interviews with people With dementia
}

\author{
Abstract \\ Despite the importance and advantages of including people with dementia in research, there are various \\ challenges for researchers and participants to their involvement. This article draws on the literature and \\ experiences of a diverse group of authors, including a person with dementia, to provide recommendations \\ about conducting research with people with dementia. Particular attention is given to in-depth interviews \\ as a qualitative technique. More specifically, topics discussed include interview guide preparation, \\ recruitment, obtaining consent/assent, conducting effective interviews, analysis and interpretation of \\ data, effective communication of research findings, and reflections and recommendations for maintaining \\ researcher and participant health. Given the current obstacles to participation in research of people with \\ dementia, this is a timely article providing useful insights to promote improved outcomes using in-depth \\ interviews.

\section{Keywords} \\ depth, conducting, recommendations, dementia, reflections, people, interviews

\section{Disciplines} \\ Education | Social and Behavioral Sciences

\section{Publication Details} \\ Cridland, E., Phillipson, L., Brennan-Horley, C. \& Swaffer, K. (2016). Reflections and recommendations for \\ conducting in-depth interviews with people With dementia. Qualitative Health Research, 26 (13), \\ 1774-1786.
}


Phillipson, L. Cridland, E., Swaffer, K. and Brennan-Horley, C. (2016).

Reflections and Recommendations for Conducting In-depth Interviews with people with dementia. Qualitative Health Research,

\begin{abstract}
Despite the importance and advantages of including people with dementia in research, there are various challenges for researchers and participants to their involvement. This article draws on the literature and experiences of a diverse group of authors, including a person with dementia, to provide recommendations about conducting research with people with dementia. Particular attention is given to in-depth interviews as a qualitative technique. More specifically, topics discussed include interview guide preparation; recruitment; obtaining consent/assent; conducting effective interviews; analysis and interpretation of data; effective communication of research findings; and reflections and recommendations for maintaining researcher and participant health. Given the current obstacles to participation in research of people with dementia, this is a timely article providing useful insights to promote improved outcomes using in-depth interviews.
\end{abstract}

\title{
Keywords
}

Dementia; qualitative interviews; research, participation; confidentiality/privacy; data collection and management; exploratory methods; relationships, research 
Historically, people with dementia have been excluded from health and social research participation (Wilkinson, 2002). However, research incorporating the subjective experiences of people living with dementia ${ }^{1}$ is on the rise (Clare, 2002; de Boer et al., 2007; von Kutzlebena, Schida, Haleka, Hollea, \& Bartholomeyczika, 2012). Factors contributing to this increasing attention include acknowledgement that there is a need to address the power inequalities in the relationship people with dementia have with others (Wilkinson, 2002). This includes a recognition that: exclusion from the research process can contribute to the objectification and negative stereotyping of people living with dementia (Cotrell, \& Schulz, 1993); people with dementia are capable of expressing their views, needs and concerns (Hellström, Nolan, Nordenfelt, \& Lundh, 2007; Smebye, \& Kirkevold, 2012); understanding the experiences of people with dementia is important for evidence-based service delivery; recognition that many people with dementia might desire to be involved in research (Abbato, 2015; Beard, 2004; de Boer, et al., 2007; Dewing, 2002); and that people with dementia might benefit from research involvement (Beard \& Fox, 2008; Hellström et al., 2007). Many of the studies including people with dementia have used qualitative approaches. Benefits of qualitative approaches include the collaborative and inclusive nature; the flexible structure;

\footnotetext{
${ }^{1}$ The term 'dementia' is used throughout this paper to refer to people experiencing significant neurocognitive impairments involving cognitive domains such as memory, language, execution of purposeful movement, recognition, visuospatial function, and self-control (American Psychiatric Association, 2013). Further, the term 'dementia' is used throughout this paper to refer to people with a diagnosis of Alzheimer's disease, vascular dementia, Lewy Body disease, fronto-temporal dementia, dementia of the 'mixed' type, and viral induced dementias.
} 
and the capacity to explore complex issues, such as mixed or ambiguous attitudes (Bond, \& Corner, 2001; Clare, 2002; Wilkinson, 2002).

The focus of this paper is in-depth interviews, which are the most commonly known and widely employed qualitative research method (Seary, \& Liamputtong, 2001). In-depth interviews involve comprehensive conversations between the researcher and interviewee, which have an overall purpose prompted by the research aims, but are strongly guided by the interviewee's perceptions, opinions, and experiences (Dickson-Swift, James, Kippen, \& Liamputtong, 2007; Minichiello, Aroni, Timewell \& Alexander, 1995). More specifically, indepth interviews aim to understand the participants' lived experience, and in this sense are considered more complex than simply asking questions and talking to people (Seary, \& Liamputtong, 2001). Interviews have been favoured as a method suitable for collecting data from people with dementia (Clarke and Keady 2002), with an emerging body of research indicating other interview methods (such as focus groups) may be less suitable for this subgroup (Bamford \& Bruce, 2000; Blackman et al., 2003).

Despite the acknowledged importance and advantages of including people with dementia in research, there are various challenges for both researchers and participants themselves in the participation in in-depth interviews (Lloyd, Gatherer, \& Kalsy, 2006). Fundamentally, the cognitive impairments inherent to the condition can make some people with dementia difficult to engage in the research process (Abbato, 2015; Dewing, 2002). More specifically, cognitive impairments implicated with dementia often involve memory difficulties, perceptual abnormalities, and challenges communicating (Lloyd, et al., 2006). Such impairments might result in vague speech, decreased vocabulary, poor reasoning of verbal information, confabulations or 'pseudo-reminiscences', perseverations, and confused word associations (Crisp, 1995; Haack, 2003; Hubbard, Downs, \& Tester, 2003; Nygard, 2006). Additionally, dementia is a progressive condition, meaning the capacity of a person 
with dementia to participate in a research interview is likely to decrease with the advancement of the disease. Together these challenges have made some researchers question the credibility and reliability of including people with dementia in in-depth interviews (Abbato, 2015; Dewing, 2002). Furthermore, the behavioural difficulties (e.g., agitation, aggression, restlessness) that sometimes result from the cognitive changes can exacerbate the practical difficulties of involving people with dementia in in-depth interviews (Abbato, 2015).

Given the specific challenges, coupled with recognition of the importance of including people with dementia in research, there is a need for improved guidance for researchers regarding the conduct of in-depth interviews with people with dementia.

\section{Methods}

In this paper, we conducted a focused literature review of scholarly articles concerning approaches to conducting in-depth interviews with people with dementia. Recommendations presented throughout the paper are derived from this review and also our own reflections in regard to the conduct of in-depth interviews. We have conducted various studies involving interviews with people with dementia and/or their carers exploring issues such as understanding experiences of living in the community (Authors 1 and 2); use of respite services (Authors 1 and 2); the lived experience of dementia (Author 3); and interviews to facilitate identification and mapping of dementia friendly places and spaces (Author 1,2 and 4). The in-depth interview approaches have included conducting interviews with people with dementia and their carers together as well as separately. We have used various approaches to facilitate the interview process such as conducting 'walk-abouts' with the participants within their home and community; using visual prompts; and mapping techniques (Authors 1, 2 and 4). Additionally, we have also worked with people with dementia and their carers in local dementia advisory groups and reference groups to inform research and community projects. 
Finally, Authors 1 and 2 have experience in the conduct of clinical interviews, one as an allied health practitioner and the other as a clinical psychologist. Author 3 is also living with dementia and so offers her unique perspectives as both a participant in research interviews and a facilitator of interviews with people with dementia.

Reflections presented throughout the paper were derived from a range of methods, such as author field notes and research journal entries, and debriefing following in-depth interviews and meetings with people with dementia and carers. Further, some reflections were derived from feedback from Author 3 regarding their experience of being involved in in-depth interviews and research processes (e.g., reflections about recruitment strategies, consent procedures, wording of interview questions, etc).

The reflections and recommendations cover all stages of the research process for the conduct of in-depth interviews, including research preparation; data collection; data analysis; and dissemination of findings (See Figure 1). The model and guidelines were also adapted from Cridland et al. (2014) who presented recommendations for doing qualitative research with individuals living with Autism Spectrum Disorder. In this light consideration is also given to the health and wellbeing of researchers and participants across all stages of the research process.

Figure 1: Stages of in-depth interviews discussed in the paper

\section{Preparation}

\section{Interview guide development}

Adequate preparation of the interview guide is vital as it underpins the interview process and influences subsequent research stages (Minichiello et al., 1995). Given the range of considerations related to interviewing people with dementia, an appropriate interview guide is 
particularly important when conducting research with this population. For example, given the likelihood of memory impairments, it is particularly important when developing an interview guide to include an introductory statement to remind participants about the general focus of the interview. Further, it may be beneficial to repeat these 'general statements' throughout the interview to ensure the participant retains a sense of the context for the interview. We have also found beginning interviews with a 'warm-up' question to be helpful when interviewing this population, as it facilitates participants to 'ease' into the conversation. This also allows the interviewer opportunity to develop a rapport with the person with dementia, which may be particularly important for this population.

From our experience, other useful considerations in interview guide development have included: using appropriate language/dementia terminology when recruiting for participants, for example, not referring to them as recruits rather as 'participants', 'experts', 'community member' and so forth. Also, using appropriate language/dementia terminology throughout the interview (e.g., avoiding referring to people with dementia as 'sufferers') and developing approaches to suit the capacity of individual participants (e.g., use of visual prompts, having joint interviews with the carer, as so forth). We have also found providing a prelude to potentially challenging interview questions (e.g., 'Some people find the next question difficult...') and oscillating between challenging and less challenging topics to be helpful. Developing single-faceted interview questions is also imperative to help reduce the demands of the interview on participants. For example asking 'What do you like about living in this house?' and then 'Are there things you would like to modify in your house?', compared to 'What do you like about living in this house or are there things you would like to modify?'. Furthermore, using a balance of positively and negatively worded questions and avoiding leading questions is an important consideration with this population to normalise and encourage open discussion of potentially difficult topics and facilitate non-bias 
responses. An example of a leading question in a study focusing on the challenges of people with dementia driving would be, 'What challenges have you encountered when driving since your diagnosis of dementia?'; opposed to a neutral question exploring the same issue, 'What have been your experiences of driving recently?'

We recommend to pilot testing the interview guide with people with dementia to identify areas of potential confusion or misinterpretation. Researchers may also connect with consumer groups of people with dementia to seek feedback on the interview guide (see Table 1 , recommendation $1 \mathrm{j}$ for more details).

\section{Participant recruitment}

Effective recruitment strategies are critical for obtaining an appropriate sample in all research studies (Dickson-Swift et al., 2007; Dickson-Swift, James, Kippen, \& Liamputtong, 2008). However, many studies involving people with dementia recruit from dementia research centres, meaning samples might not be representative of the general dementia community (Garand, Longler, Connor, \& Dew, 2009). Thus, when recruiting people with dementia it can be advantageous to promote the study through a broad range of community services and venues to facilitate obtaining an appropriate sample (Caddell \& Claire, 2002).Others have found that use of frameworks such as social marketing are useful in promoting the benefits of participation in research for people with dementia using resonant messages and tailored communication channels (Nichols, Martindale-Adams, Burns et al 2004). From our experience, future success may stem from connecting directly with a global advocacy group, such as the Dementia Alliance International (n.d.) who are the peak body for people with dementia, and whose membership is exclusive to people with a confirmed diagnosis of dementia, especially as most often trying to recruit through advocacy organisations has proven unsuccessful. Further to these, we recommend involving in-home services in reaching those people with dementia who are not actively involved in community activities to obtain 
an appropriate sample. Recruiting via a broad range of strategies and services may be particularly beneficial in avoiding potential 'over-research' which can occur when researchers employ the same centres thus engaging the same people.

We also recommend using personalised recruitment approaches. Personalised recruitment approaches can include strategies such as community information sessions held by relevant researchers and having information about the study provided to potential participants by service providers known to them. Using respectful and non-technical research language is crucial in these situations. Presentations given by members of the research team to community audiences increases the personal face of the project and can promote an increased response as people 'know' who is trying to recruit them (Author, 2015a). For example, in a project we involving in-depth interviews with people with dementia to understand their experiences of living in a community, the researchers delivered presentations at local retirement villages and community events to promote the study and recruit potential participants (Author, 2015a). Such approaches are recommended over traditional recruitment approaches with this population, which might be considered impersonal to people with dementia and/or rely on modern technology such as social media (which can result in suboptimal and/or biased recruiting).

Engaging with dementia advocates, to support the recruitment process may also prove helpful in engaging others with dementia to not only attend information sessions, but also to participate in the research. For example, the Join Dementia Research initiative (National Institute for Health Research, n.d.) in the United Kingdom links dementia researchers with members of the public who are willing to take part in studies. This initiative has reportedly been successful in promoting a $60 \%$ increase in people participating in dementia research in the past year (British Broadcasting Corporation [BBC], 2015). 
Regardless of the recruitment strategies utilised, it is recommended to provide clear and detailed information about the study in recruitment material. Also, it can be advantageous to include information about the expected positive outcomes of being involved in the study, as research indicates a significant barrier for people with dementia participating in research is the perception of limited benefit in doing so (Garand et al., 2009). This should include both the personal benefits of being involved (e.g. increased knowledge and understanding about dementia) and expected community benefits (e.g. information about how the research will be utilised to inform community programs or actions that could benefit people with dementia). Furthermore, it is recommended to target the material to both people with dementia and their carer ${ }^{2}$ because, research and our own experience indicate, the carer is frequently the person to respond to study recruitment materials (Clarke, \& Keady, 2002; Connell, Shaw, Holmes, \& Foster, 2001). More specifically, carers may be protective of the person with dementia and concerned that involvement in the research study might be confrontational and/or uncomfortable (Connell et al., 2001; Cotrell \& Schulz, 1993); reassurance that the interview will be conducted sensitively and professionally might be beneficial. For example in our experience, some carers voice concern that the person they provide care for will become upset if involved in an in-depth interview about their experiences of living with dementia. However, when reassured about the nature of the interview and the positive outcomes reported by other participants, there are more willing to explore the interest of the person with dementia about being involved.

\section{Obtaining informed and voluntary consent/assent}

\footnotetext{
${ }^{2}$ The term carer is used throughout this paper to refer to the primary support person of the person with dementia.
} 
Obtaining informed and voluntary consent is a necessary component of all research (Agre \& Rapkin, 2003). Informed consent certifies individuals understand the aims of the study, what their participation involves, potential risks and benefits of being involved in the research, and expected outcomes of the study (Agre \& Rapkin, 2003; van den Hoonaard, 2002). Informed consent is best conceptualised as an ongoing process; sought at all stages of research (Lloyd, et al., 2006; Nygard, 2006; Smebye, \& Kirkevold, 2012; van den Hoonaard, 2002).

The ability of people with dementia to provide informed consent is a central issue to their involvement in research as the condition can impair an individual's capacity to make decisions (Agronin, 2014; Dewing, 2002; Moore, \& Hollett, 2003). However, it is imperative to consider that a diagnosis of dementia does not automatically mean someone is not competent to provide informed consent; rather, it is good practice to consider participants with dementia competent to provide consent unless determined otherwise by a professional (Agronin, 2014; Kim, 2002). If it is determined that a participant with dementia is unable to provide informed consent, it is important to involve them in assent procedures (Dewing, 2007). That is, whilst it may be the legal/ethical requirement to obtain 'proxy' consent from an authorised proxy or representative on behalf of the person with dementia, this should not replace the principled approach of obtaining assent from the person with dementia themselves (Slaughter, Cole, Jennings, \& Reimer, 2007). Such approaches are in-line with personcentred and inclusive research practices (Dewing, 2002). Furthermore, if formal assent procedures are not deemed appropriate, researchers should endeavour to determine if verbal, non-verbal and behavioural indicators suggest that the person with dementia is wanting to participant in the research (Bamford \& Bruce, 2000; Dewing, 2002; Graneheim \& Jansson, 2006; Slaughter et al., 2007)

There are several strategies which can be employed to facilitate obtaining informed and voluntary consent/assent such as having a face-to-face 'preliminary meeting' with 
potential participants to specifically discuss the study and build rapport (Cotrell \& Schulz, 1993; Dalby, Sperlinger, \& Boddington, 2011; Dewing, 2002; Hubbard, et al., 2003); developing consent/assent forms which are tailored for people with dementia (Gillies, 2000); discussing research aims and participant commitments regularly throughout the interview process to encourage ongoing consent/assent (Agronin, 2014; Dewing, 2002; Cacchione, 2011; Hubbard et al., 2003); and clearly outlining confidentiality procedures. In addition to this, we have found use in verbally explaining the participant information sheets and consent forms to participants. For certain participants, this plain language verbal summary was found to maintain momentum and rapport rather than leaving the participant to read each and every page.

\section{Data Collection}

\section{Appropriate interview settings}

In this field of research, in-depth interviews are often conducted within the place of residence (Beard, 2004; Cotrell \& Schulz, 1993; Garand et al., 2009; Nygard, 2006; Watchman \& Kerr, 2014). Benefits of this approach include avoiding connotations of a clinical assessment; promoting familiarity for participants; gaining insight into the life of people with dementia; and having environmental cues which may facilitate the interview. For example, interviews about 'life at home' conducted in the home facilitate reference to the environment and prompt recall in regards to aspects that may be important, challenging, enjoyable and so forth.

The main challenge of conducting interviews within the home is ensuring interviews are completed in an appropriate private space to maintain participant confidentiality. Participants may not recognise the importance of conducting the interviews in a private space, particularly if they indicate that the relationship between the people with dementia and carer is 'open' to discussing all issues. If this is the case, it is important to discuss the need and benefits of participant confidentiality (see Table 1, recommendation 1s for more details). 
Alternatively, it may be helpful to conduct joint or 'dyad' interviews with the person with dementia and their carer, as the carer may be able to provide prompts for the person with dementia and/or clarify things the participant has mentioned (Pratt, 2002).

In some circumstances it may be more suitable to conduct interviews outside of the home environment. Such circumstances include when the person with dementia considers their home to be a private space or 'refuge' and/or when the focus of the interview dictates an alternate setting (Blackman et al., 2003; Dewing, 2002; Olsson, Lampic, Skovdahl, \& Engstrom, 2013). For example, if the focus of the research is about involvement in the community, a suitable public place may be the best setting. In these instances, considering the interview environment may be beneficial. Factors such as low noise and a public venue with minimal distractions will support the person's disabilities, and enhance the capacity of the participant.

\section{Practicalities of conducting interviews}

Numerous practical issues need to be considered when conducting qualitative research with people with dementia. Such issues include organising interviews at an appropriate time of day for participants (e.g., avoiding late afternoon interviews when participants may be tired and/or considering impact of medication); contacting the participants or carer prior to the interview to check the person with dementia is willing to be involved in the interview and/or has not had a particularly difficult day; taking time to build rapport with the person and conducting interviews at an appropriate pace (Cotrell \& Schulz, 1993; Harman \& Clare, 2006). Consideration of such issues during the planning stages of research will help facilitate effective interviews. Additionally, it may be necessary to reflect on the processes in place during the data collection stages and make appropriate changes if warranted. Interview location may also impact on interview quality because of the stress of accessing and 
negotiating unfamiliar environments (Blackman et al., 2003; Dewing, 2002; Moore \& Hollett, 2003; Olsson et al., 2013).

The skill base of interviewers is an important consideration in conductance of all indepth interviews (Brinkmann, 2007). Generally it is recommended that, at a minimum, interviewers are well acquainted with the interview guide and familiar with the interview process (Brinkmann, 2007; Minichiello et al., 1995). Additionally, personality characteristics such as patience, an open and empathetic attitude, and an ability to listen are highly valued (Brinkmann, 2007). In the context of social research with people with dementia, it is also beneficial for researchers to have a clear understanding of the lived experience of dementia at different stages of the journey and to have gained some experience in strategies that may aide communication with people with dementia. One way to facilitate this, outside of face-to-face meetings with people with dementia, is to refer to articles, blogs and books written by people with dementia (e.g., Swaffer, 2015; Dementia Diary Blog, 2015).

\section{Data analysis}

\section{Accurate analysis and interpretation of data}

When conducting in-depth interviews, data analysis and interpretation are overlapping, yet conceptually different, processes. More specifically, analysis involves the breaking down of interview data, whereas interpretation illuminates a new way of understanding the interview data while remaining faithful to the original data (van den Hoonaard, 2002). It is important to note that the analysis and interpretation stages of in-depth interviews are influenced by all other stages of research, including preparation, data collection, transcribing, and reading of transcripts (van den Hoonaard, 2002).

There are multiple issues to be considered during data analysis and interpretation of in-depth interviews with people with dementia. These include reflecting on what participants discuss as well as issues they do not discuss in interviews and having multiple researchers 
involved in the analysis and interpretation of data (Caddell \& Claire, 2002; Clare, 2002). Updating a research diary or reflective journal upon interview completion is encouraged to capture feelings and reflections as close as possible to the time they were experienced. This written record can be drawn upon as a further aide to interview analysis and interpretation (Garand et al., 2009; Moore \& Hollett, 2003).

\section{Involving participants in data analysis}

Involving participants in data analysis is a relatively recent concept with the rationale being to ensure data are accurate representations of the participants' experiences (Barbour, 2000; Braun \& Clarke, 2006; van den Hoonaard, 2002). We support the position that there are benefits of including participants in data analysis, such as giving the opportunity to reflect on their interviews and brainstorm 'themes' emerging from their interviews, and developing an appreciation of the research process. For example, our experience of the use of a dementia advisory group (made up of participants from previous research interviews) in one of our projects underscored the additional insights gained from allowing participants to brainstorm and highlight the main themes arose from that research from their perspective (Author 2015a; 2015b). Furthermore, some participants may find such involvement to be rewarding and/or therapeutic.

Several studies have included participants with dementia in data analysis processes by asking participants (who had adequate memory of their interview) to review whether they felt the preliminary themes emerging from the interview data adequately captured the issues discussed (Caddell \& Claire, 2002; Clare, 2002). Another study involved carers and/or other relevant people (e.g., staff at residential homes) in data analysis to explore whether the findings corresponded with their observations of the participants with dementia (Clare, Rowlands, Bruce, Surr, \& Downs, 2008). Possible challenges of involving participants and proxies in data analysis processes are issues with confidentiality and the possibility that 
participants may reflect on certain things they had said (e.g., challenging aspects of dementia) and express a desire for such aspects of the interview to not be included in analysis (Barbour, 2000). Such challenges may be managed by explaining confidentiality issues and normalising experiences of discomfort when reading transcripts (Barbour, 2000).

\section{Dissemination of findings}

\section{Providing feedback to participants}

Communicating feedback to participants about the results of research studies is not always considered a necessary component of the research process, beyond the publication of academic papers. However, there may be a range of benefits of taking a more comprehensive approach to dissemination and communication of results. First, feedback provides participants with findings of the study and overall outcomes of the research (e.g., policy changes, publications, funding, and so forth.) that they may not otherwise have learned. Additionally, people with dementia who participate in research are likely to have a genuine interest in the research outcomes and therefore appreciate feedback (Connell et al., 2001).

Feedback also acknowledges the significant commitment of participating in research and may facilitate participants having positive experiences of being involved in the interviews. Furthermore, providing feedback to participants may help consolidate research findings for the researcher and highlight the issues of importance for people with dementia (Keen \& Todres, 2007). Feedback about research findings and outcomes may occur periodically or at the conclusion of the research, depending on the nature of the project. Furthermore, feedback to participants may be in the form of written information and/or feedback sessions.

People with dementia have said that being involved in research helps them feel valued and that they feel they are more engaged in meaningful activities by being involved; it also helps them feel good about themselves because they feel they are helping others in the future. 
For example in an interview, Chris Roberts, a person with dementia commented, "What we then need is hope, and this is what research gives us. Taking part means I'm doing something constructive and worthwhile. I'm leaving something behind that might help others, if not myself. Any kind of research, small or large, brings with it hope that there may be a future" (BBC, 2015)

\section{Effective and ethical communication of research findings}

The communication of qualitative research (including in-depth interview studies) is traditionally confined to academic journal articles and/or conference proceedings (Keen \& Todres, 2007). This can often limit the application of research findings in facilitating positive change for the lives of those affected by the research - in this case people with dementia. Put another way, the dissemination of research findings to practice is often seen as a task beyond the research process (Keen \& Todres, 2007). However, we recommend considering the dissemination of research findings as an integral and ethical component of the research process (see Figure 1).

The intended target audience of the research is the criteria on which dissemination strategies should be based. Target audiences for research include people with dementia, carers, families, clinicians, health practitioners, policymakers, and so on. Therefore, dissemination strategies may include a range of approaches from presenting to local dementia and aged care services to key stakeholders such as governments and other policymakers. A multiple media approach to research dissemination - from printed reports and grey literature, to newspaper stories, blog posts and social media - should be considered to enhance reach, especially amongst the wider community who may not otherwise become aware of the issues and lived experience of PLD. These forms of communication and engagement are critical to maximising research impact and supporting the more active process of the translation of research evidence into policy, practice and wider community engagement. 


\section{Researcher Health}

\section{Importance of self-care}

Self-care involves a range of activities aimed at ensuring the physical, emotional, and psychological wellbeing of the researcher, such as exercise, social activities, hobbies, and travelling. The importance of self-care for researchers conducting in-depth interviews is recognised but often overlooked (Rager, 2005a; 2005b; Stamm, 1999). Researcher self-care is imperative across all aspects of the interview research process.

In discussing the potential for emotional effects of conducting in-depth interviews, it is not our intention to recommend that researchers guard against all emotional reactions to research. On the contrary, we recognise the important role of emotion in research using indepth interview approaches (Brinkmann, 2007; Rager, 2005a; 2005b), such as the ability to empathetically consider the psychological world of participants. Rather, we recommend that researchers use strategies to manage the possible negative emotional effects of conducting the interviews. Such strategies include being involved in debriefing sessions; maintaining a journal; organising interviews with adequate spacing to reduce the intensity; permitting time for reflection and considering the possible benefits of working within a research team. From our experiences the emotional connection with participants' experience has also been a motivating factor for us to personally become more involved in advocacy efforts that may help to improve the experience of those living with dementia.

\section{Developing and maintaining healthy boundaries}

When conducting in-depth interviews, it is common for researchers to negotiate multiple roles (such as data collector and empathetic listener; Lavis, 2010). In fact, these multiple roles are often considered necessary for conducting effective interview based research; whereby the researcher must conduct ethical practices while also developing authentic relationships with participants (Lavis, 2010). Developing and maintaining healthy boundaries 
around researcher roles is critical for conducting research in this field, given the potential for role confusion that may result when involving people with dementia in research (Nygard, 2006).

Boundary confusion is a bidirectional process whereby misunderstandings from either the researchers or participants can result in inappropriate roles (Brinkmann, 2007). For example, an interviewer giving advice and/or discussing issues other than those directly related to the research topic. Strategies to help maintain healthy boundaries include a clear understanding for both researchers and participants about the role of the researcher and limitations to this role, and using various monitoring strategies such as other researchers attending the interviews or reading the transcripts. Another strategy involves permitting new researchers to accompany more experienced colleagues to interviews. This allows opportunity for experiencing how positive personality characteristics can affect the interview setting. Furthermore, exposing new researchers to what can at times be an emotionallycharged environment alongside more experienced researchers can help them to develop emotional coping strategies before embarking upon their own fieldwork.

\section{Participant Health}

The potential impact of research participation is usually considered by researchers as part of the ethical considerations involved in the conduct of research. Such considerations usually include the consideration of risks, benefits and consent (National Health and Medical Research Council, 2015). We would suggest that there may be a need to consider participant health beyond these traditional realms. In one recent project (Author, 2015a), involvement in a research interview was the first time, for some participants that they have been involved in an extended process of talking or reflecting on their circumstances and the impact of dementia on their lives and relationships. For some, this led to sadness, distress or anger, which resulted in the person identifying the need for professional support or grief and loss 
counselling. To support participant health, it was essential as researchers that we had a good knowledge of local care services and were able to provide information about these services as required.

For others, it was the first time they had openly or publically acknowledged that they had a diagnosis of dementia. In this sense, it was a 'coming out' experience, which led them to desire contact with other people with dementia and to understand more about the way others with the disease were learning to live with their symptoms. In our local area, there were no active face to face support groups for people living with dementia, so we, as researchers took up an advocacy role to support the creation of a local group. The initiation of this group was supported by Author 3 who lives with dementia, and was able to draw on her experience of the process that she had utilised to support the creation of a national Dementia Consumer Advisory Group (organisation name removed for blind review). Whilst others may find this point contentious, we believed this role was part of our ethical commitment to meeting the needs of our participants that were made evident as a result of their participation in the research process. An alternative to support the connection of people with dementia with others who are also living with the condition is to raise the awareness of online support groups (e.g., Dementia Alliance International, n.d.).

Table 1 provides detailed recommendations based on the issues discussed throughout the article. The recommendations are based on the literature and experiences from our involvement in semi-structured interviews with people with dementia.

(Insert Table 1 here)

\section{Discussion}


There are multiple imperatives to improve the participation of people with dementia in the research process. These include benefits for the person with dementia (Beard \& Fox, 2008; Hellström et al., 2007); improved research outcomes (Abbato, 2015; Beard, 2004; de Boer, et al., 2007; Dewing, 2002); and the need to improve the practice of researchers studying dementia (Cotrell \& Schulz, 1993).

In this article, we have provided recommendations and reflections about conducting in-depth interviews with people with dementia that considers the process from preparation, to data collection, data analysis, and dissemination of findings, and considers strategies to maintain and promote researcher and participant health throughout the process.

Although previous research had stressed the importance of the careful preparation of the interview guide for semi-structured interviews with people with dementia (Minichiello et al., 1995) this paper has also highlighted the specific role of the interview guide in assisting researchers in the process of establishing a rapport within the interview process. The utility of providing strategies to support the disabilities caused by the symptoms of dementia, such as repetition and rephrasing of questions, developing single-faceted interview questions and the use of visual prompts or stimulus material to prompt recall within the guide are highlighted, along with the benefits of pilot testing the interview guide to identify areas for improvement. Table 1 provides useful features to consider when developing an interview guide, which might assist with the auditing of interview guides prior to piloting the guide with participants. Strategies to promote participation in research by people with dementia have also been considered. Previous research has highlighted the potential benefit of promoting studies through not only hospital but also through community channels (Caddell \& Claire, 2002) or dedicated social marketing strategies (Nichols et al., 2004). In this paper, we have extended this list of strategies from our own experience, highlighting the essential need to build trust and rapport with participants and their carers' and also to promote the benefits of 
participation (both for the person themselves and the broader community). To achieve this, researchers must carefully consider the design of their studies to ensure they are maximising participant benefit as part of the study objectives (see Crockett, Downey, Fuat Firat, Ozanne, \& Pettigrew, 2013 for further reading regarding transformative consumer research approaches). The importance of strategies for promoting informed consent and/or assent and the consistency of these approaches with person centred care philosophies is also emphasised (Bamford \& Bruce, 2000; Dewing, 2002; Graneheim \& Jansson, 2006; Slaughter et al., 2007).

This article clearly re-emphasises the importance of considering the impact of place and time in the process of data collection with participants with dementia. Previous research has highlighted place considerations in the conduct of semi-structured interviews in regards to the impact on participant comfort, recall, and privacy (Blackman et al., 2003; Dewing, 2002; Olsson et al., 2013). In addition, this article also brings into greater focus the temporal aspects which should be considered during interviews including: time for the researcher to build rapport with the person with dementia; the way that time of day might impact on participant concentration and performance; 'pacing' of the interview; and the need for the researcher to be periodically evaluating if the person with dementia would benefit from a 'break' (Cotrell \& Schulz, 1993; Harman \& Clare, 2006).

Finally, the article considers the important interaction of skills, personal attributes and knowledge that the researcher brings to the interview. In this, the characteristics of patience and empathy have been highlighted (Brinkman, 2007). In addition our recent experiences call us to suggest the benefit of researchers being equipped with knowledge of the lived experience of dementia at different stages of the journey, as well as skills which might aide their communication with people with dementia (Alzheimer's Australia, n.d. b;c). 
Looking beyond the use of specific analytic techniques, this paper highlights the potential benefits of improving accuracy as well as adding further benefits for participants and or their carers through involving them in data analysis (Caddell \& Claire, 2002; Clare, 2002). This should be undertaken by researchers with an understanding of some the challenges in doing so, such as confidentiality and discomfort that be associated with this level of involvement (Barbour, 2000).

In this article, we have posited that research which seeks to provide a mutually beneficial exchange for participants with dementia should consider feedback to participants a necessary part of the research process. Provision of participant feedback is likely to produce benefit to the person with dementia through acknowledgement of the significant commitment that they have made through their involvement in the research, and in addition may produce an exchange which provides new insights or knowledge for the personal with dementia and/or the researcher (Connell et al., 2001; Keen, \& Todres, 2007). From our recent research experience working with a local Dementia Advisory Group (Author, 2015a), feedback for an audience with dementia should be timely, time-limited, and formatted to ensure the use of 'dementia-friendly' language and the use of simplified data and/or diagrams to cater for the needs of an audience who are cognitively impaired and may also have visual deficits associated with the syndrome. Using visual aids such as a power point or printed sheets can also assist during the interview process, as a multisensory approach is more supportive of the cognitive and language disabilities of dementia. To maximise impact researchers should also consider formats and channels for research dissemination to a variety of audience involved in the care of people with dementia including dementia and aged care services to key stakeholders such as governments and other policymakers.

Finally, the considerations of researcher and participant health are brought to the fore in this article. Both acknowledge the potential impact of participation in in-depth interviews 
on the emotional and psychological wellbeing of both the researcher and the person with dementia. For the researcher, we suggest this can be supported through the maintenance of healthy boundaries and through strategies such as debriefing sessions; journaling, allowing time for reflection, and working within a research team or network. For the person with dementia, we believe the research process should be part of a response which contributes to their health and wellbeing through strategies which can connect people with dementia to relevant services and supports in response to needs that become evidence during the research process.

A major challenge of conducting research in this field is obtaining a representative sample. First, recruitment of people with dementia is difficult as many of the commonly utilised methods of recruitment may not be suitable. Second, many of the participants responding to recruitment material may be a select group (e.g., more confident about engaging in research, motivated to help others, have come to terms with their diagnosis of dementia; Caddell \& Claire, 2002; Cotrell \& Schulz, 1993; Garand et al., 2009).

Furthermore, attempts to understand more about the reasons why some people with dementia and/or carers choose not to participate in research are hindered by confidentiality issues and the need to respect their decision not to be involved in research (Cotrell \& Schulz, 1993).

Additionally, existing interview research has largely involved people with early stages of dementia (Beard, 2004; Caddell \& Claire, 2002; Clare, 2002; Hubbard et al., 2003). However, there is also a need to explore the subjective experiences of people with moderate to severe levels of impairment (Clare et al., 2008; Cowdell, 2008). Such research will need to development suitable strategies to match the capacity of such individuals and might benefit from utilising approaches such as observation and interviews with carers (Clare et al., 2008).

Research exploring the experiences of people with dementia belonging to cultural minority groups is also lacking (Garand et al., 2009). Additionally, whilst there have been 
some longitudinal interview studies involving people with dementia (e.g., Clare, 2002; Clare, Roth, \& Pratt, 2005; Sabat, 2002), the vast majority are cross sectional. Longitudinal or studies incorporating a 'follow-up' have the potential to capture changes and adaptions in the lived experiences of people with dementia over time (Caddell \& Claire, 2002; Cotrell \& Schulz, 1993; Garand et al., 2009). Such studies might also assist us to generate a more holistic picture of the impact of research participation on the health and wellbeing of people with dementia.

Finally, the recent experiences of one author (Author 3) suggests there may be value in further exploring the use of other interview methods such as focus groups, especially if these groups can be facilitated by a researcher who is living with dementia. This is based on her recent pioneering work in the use of focus groups with those with dementia, who were very keen to take part when they knew it was another person with dementia facilitating the group.

\section{Conclusion}

Conducting in-depth interviews with people with dementia poses many challenges, as highlighted by the range of considerations discussed throughout. Clearly, there is more to be done around developing 'dementia friendly' interview methods to maximise these individuals' capacities to share their perspectives and experiences, especially for those people with more advanced dementia (Dewing, 2002; Phinney, 1998). However, this paper highlights that there is much that can be gained from supportive approaches that can assist researchers, which in turn will help to help change the view of people living with dementia from a subgroup that need to be studied, to an appreciation of them as people whose perspectives can help us understand more about living with dementia (Cotrell \& Schulz, 1993). 


\section{References}

Abbato, S. (2015). The case for evaluating process and worth: Evaluation of a programme for carers and people with dementia. Case Study Evaluation: Past, Present and Future Challenges, 107-131.

Agre, P., \& Rapkin, B. (2003). Improving informed consent: A comparison of four consent tools. Ethics and Human Research, 25(6), 1-7.

Agronin, M. E. (2014). Alzheimer's Disease and other Dementias: A Practical Guide (pp. 412-438). New York: Routledge.

Alzheimer's Australia (n.d., a). Alzheimer’s Australia Dementia Advisory Committee. Retrieved from https://fightdementia.org.au/national/about-us/consumergroups/dementia-advisory-committee

Alzheimer's Australia (n.d., b). Dementia language guidelines. Retrived from https://fightdementia.org.au/sites/default/files/full-language-guidelines.pdf

Alzheimer's Australia (n.d., c). Talk to me: Good communication tips for talking to people with dementia. Retrieved from https://fightdementia.org.au/sites/default/files/TalkToMe_Brochure_FoldedDL_HR.p df

American Psychiatric Association. (2013). Diagnostic and Statistical Manual of Mental Disorders (5th ed.). Arlington, VA: American Psychiatric Publishing.

Author (2015a).

Author (2015b).

Bamford, C., \& Bruce, E. (2000). Defining the outcomes of community care: The perspectives of older people with dementia and their carers. Ageing and Society, 20(5), 543-570. doi: 10.1017/s0144686x99007898 
Barbour, R. S. (2000). The role of qualitative research in broadening the 'evidence base' for clinical practice. Journal of Evaluation in Clinical Practice, 6(2), 155-163.

Beard, R. L. (2004). In their voices: Identity preservation and experiences of Alzheimer's disease. Journal of Aging Studies, 18(4), 415-428. doi: 10.1016/j.jaging.2004.06.005

Beard, R. L., \& Fox, P. J. (2008). Resisting social disenfranchisement: Negotiating collective identities and everyday life with memory loss. Social Science \& Medicine, 66(7), 1509-1520. doi: 10.1016/j.socscimed.2007.12.024

Beard, R. L., Knauss, J., \& Moyer, D. (2009). Managing disability and enjoying life: How we reframe dementia through personal narratives. Journal of Aging Studies, 23, 227-235.

Blackman, T., Mitchell, L., Burton, E., Jenks, M., Parsons, M., Raman, S., \& Williams, K. (2003). The accessibility of public spaces for people with dementia: A new priority for the 'open city'. Disability and Society, 18(3), 357-371.

Bond, J. B. A., \& Corner, L. (2001). Researching dementia: Are there unique methodological challenges for health services research? Ageing and Society, 21, 95-116.

Braun, V., \& Clarke, V. (2006). Using thematic analysis in psychology. Qualitative Research in Psychology, 3(77-101).

Brinkmann, S. (2007). The good qualitative researcher. Qualitative Research in Psychology, 4(1-2), 127-144. doi: 10.1080/14780880701473516

British Broadcasting Corporation (2015). Dementia research boosted by surge in volunteers. Retrieved from http://www.bbc.com/news/health-33915909

Cacchione, P.Z. (2011). People with dementia: Capacity to consent to research participation. Clinical Nursing Research, 20, 223-227.

Caddell, L. S., \& Claire, L. (2002). I'm still the same person: The impact of early-stage dementia on identity. Dementia, 10(3), 379-398. 
Clare, L. (2002). We'll fight it as long as we can: Coping with the onset of Alzheimer's disease. Aging \& Mental Health, 6(2), 139-148. doi: 10.1080/13607860220126826

Clare, L., Roth, I., \& Pratt, R. (2005). Perceptions of change over time in early-stage Alzheimer's disease: Implications for understanding awareness and coping style. Dementia, 4(4), 487-520. doi: 10.1177/1471301205058304

Clare, L., Rowlands, J., Bruce, E., Surr, C., \& Downs, M. (2008). 'I don't do like I used to do': A grounded theory approach to conceptualising awareness in people with moderate to severe dementia living in long-term care. Social Science \& Medicine, 66(11), 2366-2377. doi: 10.1016/j.socscimed.2008.01.045

Clark, C.L., \& Keady, J. (2002). Getting down the brass tacks: A discussion of data collection with people with dementia. In H. Wilkinson (ed.), The Perspectives of People with Dementia: Research Methods and Motivations (pp. 25-46). London, Jessica Kingsley Publishers.

Connell, C. M., Shaw, B. A., Holmes, S. B., \& Foster, N. L. (2001). Caregivers' attitudes toward their family members' participation in Alzheimer's disease research: Implications for recruitment and retention. Alzheimer Disease and Associated Disorders 15, 137-145.

Cotrell, V., \& Schulz, R. (1993). The perspective of the patient with Alzheimer's disease: A neglected dimension of dementia research. The Gerontologist, 33(2), 205-211. doi: 10.1093/geront/33.2.205

Cowdell, F. (2008). Engaging older people with dementia in research: Myth or possibility. International Journal of Older People Nursing, 3, 29-34.

Cridland, E. K., Jones, S. C., Caputi, P., \& Magee, C. A. (2014). Qualitative research with families living with autism spectrum disorders: Recommendations for conducting semi-structured interviews. 40:1, 78-91, DOI: 10.3109/13668250.2014.964191 
Crisp, J. (1995). Making sense of the stories that people with Alzheimer's tell: A journey with my mother. Nursing Inquiry, 2, 133-140.

Crockett, D., Downey, H., Fuat Firat, A., Ozanne, J.L., \& Pettigrew, S.(2013).

Conceptualizing a transformative research agenda. Journal of Business Research, 66(8), 1171-1178.

Dalby, P., Sperlinger, D., \& Boddington, S. (2011). The lived experience of spirituality and dementia in older people living with mild to moderate dementia. Dementia, 11, 75-94.

de Boer, M. E., Hertogh, C. M. P. M., Dröes, R.-M., Riphagen, I. I., Jonker, C., \& Eefsting, J. A. (2007). Suffering from dementia - The patient's perspective: A review of the literature. International Psychogeriatrics, 19(6), 1021-1039. doi:

$10.1017 / \mathrm{s} 1041610207005765$

Dementia Alliance International (n.d). Support and advocacy: Of, by and for people with dementia. Retrieved from http://www.dementiaallianceinternational.org/

Dementia Diary Blog (2015). Retrived from https://www.facebook.com/TheDementiaDiaryBlog

Dewing, J. (2002). From ritual to relationship: A person-centred approach to consent in qualitative research with older people who have a dementia. Dementia, 1(2), 157-171. doi: $10.1177 / 147130120200100204$

Dewing, J. (2007). Participatory research: A method for process consent with persons who have dementia. Dementia 6, 111-125.

Dickson-Swift, V., James, E. L., Kippen, S., \& Liamputtong, P. (2007). Doing sensitive research: What challenges do qualitative researchers face? Qualitative Research, 7(3), $327-353$. 
Dickson-Swift, V., James, E. L., Kippen, S., \& Liamputtong, P. (2008). Risk to researchers in qualitative research on sensitive topics: Issues and strategies. Qualitative Health Research, 18(1), 133-144.

Garand, L., Longler, J. H., Connor, K. O., \& Dew, M. A. (2009). Diagnostic labels, stigma and participation in research related to dementia and mild cognitive impairment. Research in Gerontological Nursing, 2(2), 112-121. doi: 10.3928/1940492120090401-04.

Gillies, B. A. (2000). A memory like clockwork: Accounts of living through dementia. Aging \& Mental Health, 4(4), 366-374. doi: 10.1080/713649961

Graneheim, U. H., \& Jansson, L. (2006). The meaning of living with dementia and disturbing behaviour as narrated by three persons admitted to a residential home. Journal of Clinical Nursing, 15(11), 1397-1403. doi: 10.1111/j.1365-2702.2006.01476.x

Haak, N. J. (2003). "Do you hear what I mean?": A lived experience of disrupted communication in mid-to-late stage Alzheimer's disease. Alzheimer's Care Quarterly, $4(1), 26-40$.

Harman, G., \& Clare, L. (2006). Illness representations and lived experience in early-stage dementia. Qualitative Health Research, 16(4), 484-502. doi:

\section{$10.1177 / 1049732306286851$}

Hellström, I., Nolan, M., Nordenfelt, L., \& Lundh, U., (2007). Ethical and methodological issues in interviewing persons with dementia. Nursing Ethics, 14(5), 608-619. doi: $10.1177 / 0969733007080206$

Hubbard, G., Downs, M. G., \& Tester, S. (2003). Including older people with dementia in research: Challenges and strategies. Aging \& Mental Health, 7(5), 351-362. doi: $10.1080 / 1360786031000150685$ 
Keen, S., \& Todres, L. (2007). Strategies for disseminating qualitative research findings: Three exemplars. Forum: Qualitative Social Research, 8(3).

Kim, S. Y. H., Karlawish, J. H. T., \& Caine, E. D. (2002). Current state of research on decision-making competence of cognitively impaired elderly persons. The American Journal of Geriatric Psychiatry, 10(2), 151-165.

Lavis, V. (2010). Multiple researcher identities: Highlighting tensions and implications for ethical practice in qualitative interviewing. Qualitative Research in Psychology, 7(4), 316-331. doi: 10.1080/14780880902929506

Lloyd, V., Gatherer, A., \& Kalsy, S. (2006). Conducting qualitative interview research with people with expressive language difficulties. Qualitative Health Research, 16, 13861404.

Minichiello, V., Aroni, R., Timewell, E., \& Alexander, L. (1995). In-Depth Interviewing (2 ed.). Sydney: Longman.

Moore, T. F., \& Hollett, J. (2003). Giving voice to persons living with dementia: The researcher's opportunities and challenges. Nursing Science Quarterly, 16(2), 163-167. doi: $10.1177 / 0894318403251793251793$

National Health and Medical Research Council (2015). National Statement on Ethical Conduct in Human Research. Paper ID: 1864962755. From https://www.nhmrc.gov.au/guidelines-publications/e72

National Institute for Health Research (n.d.). Join Dementia Research. Retrieved from https://www.joindementiaresearch.nihr.ac.uk

Nichols, L., Martindale-Adams,J., Burns,R., Coon, D., Ory, M., Mahoney, D. et al. (2004). Social Marketing as a Framework for Recruitment: Illustrations From the REACH Study, Journal of Aging and Health. 2004 Nov; 16(5 Suppl): 157S-176S.vdoi: $10.1177 / 0898264304269727$ 
Nygård, L. (2006). How can we get access to the experiences of people with dementia? Scandinavian Journal of Occupational Therapy, 13(2), 101-112. doi: doi:10.1080/11038120600723190

Olsson, A., Skovdahl, K., Engström, M., \& Lampic, C. (2013). Persons with early-stage dementia reflect on being outdoors: A repeated interview study. Aging \& Mental Health, 17(7), 793.

Phinney, A. (1998). Living with dementia from the patient's perspective. Journal of Gerontological Nursing, 24(6), 8-15.

Pratt, R. (2002). 'Nobody’s ever asked how I felt' In H. Wilkinson (ed.), The Perspectives of People with Dementia: Research Methods and Motivations (pp. 25-46). London, Jessica Kingsley Publishers.

Rager, K. B. (2005a). Compassion stress and the qualitative researcher. Qualitative Health Research, 15, 423-430.

Rager, K. B. (2005b). Self-care and the qualitative researcher: When collecting data can break your heart. Educational Researcher, 34(4), 23-27. doi:

10.3102/0013189x034004023

Roth, C.L., \& Pratt, R (2005). Perceptions of change over time in early-stage Alzheimer's disease: Implications for understanding awareness and coping style. Dementia, 4, 487-520. doi: 10.1177/1471301205058304

Sabat, S. (2002). Epistemological issues in the study of insight in people with Alzheimer's disease. Dementia, 1, 279-293.

Seary, T., \& Liamputtong, P. (2001). The in-depth interviewing method in health. In P. Liamputtong (ed.), Research Methods in Health-Foundations for Evidence-Based Practice (p. 43-60). Melbourne, Oxford Press. 
Slaughter, S., Cole, D., Jennings, E., \& Reimer, M. A. (2007). Consent and assent to participate in research from people with dementia. Nursing Ethics, 14(1), 27-40. doi: $10.1177 / 0969733007071355$

Smebye, K., \& Kirkevold, M. (2012). How do persons with dementia participate in decision making related to health and daily care? A multi-case study. BMC Health Services, 12(1), 241-245.

Stamm, B. H. (1999). Secondary Traumatic Stress: Self-Care Issues for Clinicians, Researchers, and Educators (Second ed.). Lutherville: Sidran Press.

Swaffer, K. (2015). Creating life with words: Inspiration, love and truth. Retrived from http://kateswaffer.com/daily-blog/

van den Hoonaard, W. C. (2002). Walking the Tightrope: Ethical Issues for Qualitative Researchers. Buffalo: University of Toronto Press.

von Kutzlebena, M., Schmida, W., Haleka, M., Hollea, B., \& Bartholomeyczika, S. (2012). Community-dwelling persons with dementia: What do they need? What do they demand? What do they do? A systematic review on the subjective experiences of persons with dementia. Aging \& Mental Health, 16(3), 378-390. doi:

$10.1080 / 13607863.2011 .614594$

Watchman, K., \& Kerr, D. (2014). Intellectual Disability and Dementia: Research into Practice. London: Jessica Kingsley Publishers.

Wilkinson, H. (2002). The Perspectives of People with Dementia. Research Methods and Motivations. London, Jessica Kingsley Publishers. 


\section{Table 1: Recommendations for conducting qualitative interviews with people with dementia}

\begin{tabular}{|c|c|c|c|c|}
\hline & $\begin{array}{l}\text { Research } \\
\text { stage }\end{array}$ & Recommendation & General rationale & Rationale for research with PWD \\
\hline 1a. & $\begin{array}{l}\text { Preparation: } \\
\text { Interview guide } \\
\text { development }\end{array}$ & $\begin{array}{l}\text { Include an } \\
\text { introductory statement } \\
\text { and reminder } \\
\text { statements } \\
\text { periodically } \\
\text { throughout the } \\
\text { interview. }\end{array}$ & $\begin{array}{l}\text { An introductory statement before } \\
\text { commencing the interview facilitates a clear } \\
\text { and concise introduction to the interview } \\
\text { process and can be helpful in reminding } \\
\text { participants about the general focus of the } \\
\text { interview. } \\
\text { A reminder statement in regards to the } \\
\text { interview incorporated at regular intervals } \\
\text { reorients the participant to the interview } \\
\text { context }\end{array}$ & $\begin{array}{l}\text { Both introductory and reminder statements orient } \\
\text { and re-orient the PWD to the interview context, } \\
\text { This is may be particularly relevant given the } \\
\text { memory difficulties inherent to the condition. } \\
\text { 'Reminder cards' with a brief summary of the } \\
\text { purpose of the interview have also been used with } \\
\text { PWD (Clare et al., 2005) }\end{array}$ \\
\hline $1 \mathrm{~b}$. & $\begin{array}{l}\text { Preparation: } \\
\text { Interview guide } \\
\text { development }\end{array}$ & $\begin{array}{l}\text { Begin interviews by } \\
\text { building rapport and } \\
\text { the use of a "warm- } \\
\text { up" question. }\end{array}$ & $\begin{array}{l}\text { Including questions which aim to build } \\
\text { rapport and establish a connection are } \\
\text { important for settling participants into the } \\
\text { interview process. } \\
\text { A warm-up question helps 'set the scene' } \\
\text { for the interview while also allowing } \\
\text { participants to experience mastery and relax } \\
\text { into the interview. }\end{array}$ & $\begin{array}{l}\text { Time to establish the identity of the researcher and } \\
\text { develop comfort are important to establish trust } \\
\text { and context for PWD (See } 2 \mathrm{~d} \text { for more information } \\
\text { about rapport building). } \\
\text { Facilitating mastery at the beginning of the } \\
\text { interview may be helpful in encouraging PWD to } \\
\text { relax into the interview process and decrease any } \\
\text { apprehension or agitation, which is particularly } \\
\text { relevant for this population. }\end{array}$ \\
\hline 1c. & $\begin{array}{l}\text { Preparation: } \\
\text { Interview guide } \\
\text { development }\end{array}$ & Use appropriate & $\begin{array}{l}\text { When conducting research with specific } \\
\text { populations (e.g., individuals diagnosed } \\
\text { with a health condition, and so forth) it is } \\
\text { important to use 'value-neutral' and } \\
\text { sensitive language. It may also be beneficial } \\
\text { to be flexible with terminology, using } \\
\text { language preferred by individual } \\
\text { participants. }\end{array}$ & $\begin{array}{l}\text { Avoid terms which position PWD and carers as } \\
\text { 'sufferers' or those 'afflicted' by dementia (Beard, } \\
\text { Knauss, \& Moyer, 2009). Furthermore, PWD may } \\
\text { use different terminology to refer to dementia (e.g., } \\
\text { memory problem, Alzheimer's, and so } \\
\text { forth.)(Clare, 2002; Linda Clare, et al., 2005; } \\
\text { Garand, et al., 2009; Gillies, 2000). Ask what } \\
\text { terminology each participant feels comfortable } \\
\text { with rather than assuming or imposing } \\
\text { terminology. }\end{array}$ \\
\hline $1 \mathrm{~d}$. & $\begin{array}{l}\text { Interview guide } \\
\text { development }\end{array}$ & $\begin{array}{l}\text { to suit the capacity of } \\
\text { each participant }\end{array}$ & $\begin{array}{l}\text { Flexible interview approaches can be used } \\
\text { to suit the capacity and needs of individual } \\
\text { participants and help ensure participants } \\
\text { who find complex approaches too }\end{array}$ & $\begin{array}{l}\text { to facilitate inclusion of those with more advanced } \\
\text { conditions in in-depth interview research. Such } \\
\text { approaches include having preliminary interviews }\end{array}$ \\
\hline
\end{tabular}




\begin{tabular}{|c|c|c|c|c|}
\hline & $\begin{array}{l}\text { Research } \\
\text { stage }\end{array}$ & Recommendation & General rationale & \\
\hline & & & $\begin{array}{l}\text { demanding are not disempowered and/or } \\
\text { decline from participating in the research. }\end{array}$ & $\begin{array}{l}\text { with carers to highlight areas for potential } \\
\text { discussion (Clare, 2002); combining interviews } \\
\text { with observations ( Beard, 2004; Haack, 2003; } \\
\text { Hubbard, et al., 2003); conducting follow-up } \\
\text { interviews of the same format to review, clarify, } \\
\text { and expand on issues discussed (Phinney, 1998); } \\
\text { and triangulating interviews with contextual } \\
\text { information (e.g., medical records; Linda. Clare, et } \\
\text { al., 2008; or carer perspectives). Additionally, } \\
\text { PWD may have co-occurring conditions (e.g., } \\
\text { hearing or vision difficulties) which should be } \\
\text { considered because they may influence their } \\
\text { involvement in the interview. }\end{array}$ \\
\hline $1 \mathrm{e}$. & $\begin{array}{l}\text { Preparation: } \\
\text { Interview guide } \\
\text { development }\end{array}$ & $\begin{array}{l}\text { Provide a prelude to } \\
\text { challenging questions. }\end{array}$ & $\begin{array}{l}\text { A prelude prepares participants for the } \\
\text { upcoming question and normalises any } \\
\text { feelings of confusion or discomfort they } \\
\text { may have. }\end{array}$ & $\begin{array}{l}\text { There are topics that PWD may find challenging to } \\
\text { talk about, such as losses or difficulties associated } \\
\text { with having dementia and recalling recent events } \\
\text { (Cotrell \& Schulz, 1993). }\end{array}$ \\
\hline 1f. & $\begin{array}{l}\text { Preparation: } \\
\text { Interview guide } \\
\text { development }\end{array}$ & $\begin{array}{l}\text { Structure interview } \\
\text { guide to have } \\
\text { challenging questions } \\
\text { followed by easier } \\
\text { topics. }\end{array}$ & $\begin{array}{l}\text { Oscillating between challenging and less } \\
\text { challenging topics can help reduce the } \\
\text { emotional and psychological demands of the } \\
\text { interview on participants. The most } \\
\text { efficacious 'easy' questions will foster } \\
\text { mastery and also relate in some way to the } \\
\text { research topic (Minichiello et al., 1995). }\end{array}$ & $\begin{array}{l}\text { 'Easy' topics of conversation with PWD may } \\
\text { involve reminiscing about past positive } \\
\text { experiences. }\end{array}$ \\
\hline 1g. & $\begin{array}{l}\text { Preparation: } \\
\text { Interview guide } \\
\text { development }\end{array}$ & $\begin{array}{l}\text { Develop single- } \\
\text { faceted questions. }\end{array}$ & $\begin{array}{l}\text { Single-faceted questions are easier for } \\
\text { participants to understand and accurately } \\
\text { interpret. }\end{array}$ & $\begin{array}{l}\text { Single-faceted questions suit the processing style } \\
\text { of PWD and facilitate accurate interpretation of } \\
\text { questions (Harman \& Clare, 2006; Nygard, 2006). } \\
\text { Recall may also be prompted by keeping to one } \\
\text { topic or idea per question (Harman \& Clare, 2006). } \\
\text { Confusion caused by difficulty understanding } \\
\text { multifaceted questions may disempower a PWD } \\
\text { and could led to feelings of frustration or } \\
\text { hopelessness. }\end{array}$ \\
\hline 1h. & $\begin{array}{l}\text { Preparation: } \\
\text { Interview guide }\end{array}$ & $\begin{array}{l}\text { Use both positively } \\
\text { and negatively framed }\end{array}$ & $\begin{array}{l}\text { Using positively and negatively framed } \\
\text { questions is good practice in all qualitative }\end{array}$ & $\begin{array}{l}\text { Interviews with PWD are likely to involve } \\
\text { discussion of a range of positive, negative, and }\end{array}$ \\
\hline
\end{tabular}




\begin{tabular}{|c|c|c|c|c|}
\hline & $\begin{array}{l}\text { Research } \\
\text { stage }\end{array}$ & Recommendation & General rationale & Rationale for research with PWD \\
\hline & development & questions. & $\begin{array}{l}\text { research. Such questions facilitate } \\
\text { discussion of both rewarding and } \\
\text { challenging experiences, attitudes, and } \\
\text { feelings, and contribute to a balanced } \\
\text { understanding of issues. }\end{array}$ & $\begin{array}{l}\text { ambiguous experiences, attitudes, and feelings. In } \\
\text { doing so, acknowledge that not all participants will } \\
\text { share the range of experiences to help normalise } \\
\text { and encourage open discussion of potentially } \\
\text { difficult topics. }\end{array}$ \\
\hline $1 \mathrm{~g}$ & $\begin{array}{l}\text { Preparation: } \\
\text { Interview guide } \\
\text { development }\end{array}$ & $\begin{array}{l}\text { Consider the utility of } \\
\text { visual aids or stimulus } \\
\text { materials to prompt } \\
\text { recall \& response } \\
\text { depth }\end{array}$ & $\begin{array}{l}\text { The use of visual stimulus materials (e.g. } \\
\text { photographs or maps) may assist with } \\
\text { prompting recall and context when } \\
\text { questions are not sufficient to gain a } \\
\text { meaningful response. }\end{array}$ & $\begin{array}{l}\text { Visual stimuli may be particularly relevant for } \\
\text { prompting recall for people with dementia given } \\
\text { the memory impairments inherent to the condition } \\
\text { (Author, 2015a; See } 2 \mathrm{~d} \text { for more information about } \\
\text { visual stimuli). }\end{array}$ \\
\hline 1i. & $\begin{array}{l}\text { Preparation: } \\
\text { Interview guide } \\
\text { development }\end{array}$ & $\begin{array}{l}\text { Avoid using leading } \\
\text { questions. }\end{array}$ & $\begin{array}{l}\text { All research studies have aims and } \\
\text { hypotheses; however, it is important that } \\
\text { interview questions do not elicit responses } \\
\text { solely in support of these hypotheses. }\end{array}$ & $\begin{array}{l}\text { When responding to questions, PWD may be likely } \\
\text { to discuss things specific to the question posed } \\
\text { rather than using that question as a platform on } \\
\text { which to elaborate. }\end{array}$ \\
\hline $1 \mathrm{j}$. & $\begin{array}{l}\text { Preparation: } \\
\text { Interview guide } \\
\text { development }\end{array}$ & $\begin{array}{l}\text { Pilot test the interview } \\
\text { guide. }\end{array}$ & $\begin{array}{l}\text { Pilot testing the interview guide is helpful in } \\
\text { estimating the time needed to conduct the } \\
\text { interview and promote researcher familiarity } \\
\text { with the interview guide. }\end{array}$ & $\begin{array}{l}\text { Pilot testing with a PWD may be useful in } \\
\text { identifying questions that may be confusing or } \\
\text { open to misinterpretation. Researchers may also be } \\
\text { able to connect with consumer groups of people } \\
\text { with dementia (e.g., Dementia Alliance } \\
\text { International [n.d.]; and the Alzheimer's Australia } \\
\text { Dementia Advisory Committee [n.d., a]) to seek } \\
\text { feedback about the interview guide and other } \\
\text { project materials (e.g., participant information } \\
\text { sheets). }\end{array}$ \\
\hline $1 \mathrm{k}$. & $\begin{array}{l}\text { Preparation: } \\
\text { Participant } \\
\text { recruitment }\end{array}$ & $\begin{array}{l}\text { Promote the study } \\
\text { through a range of } \\
\text { avenues, especially } \\
\text { interpersonal channels }\end{array}$ & $\begin{array}{l}\text { Promoting the study through a range of } \\
\text { avenues (such as community organisations } \\
\text { and public venues) will increase the number } \\
\text { of potential participants that the study is } \\
\text { advertised to. } \\
\text { Promoting the study through interpersonal } \\
\text { channels is also likely to increase the } \\
\text { responses }\end{array}$ & $\begin{array}{l}\text { Relevant places of recruitment for PWD may } \\
\text { include dementia and aged care services, } \\
\text { community social groups, general practitioner } \\
\text { surgeries, volunteer organisations, and carers } \\
\text { groups. Additionally, utilising in-home services } \\
\text { may facilitate recruitment of PWD who are not } \\
\text { involved in community activities. Snowballing } \\
\text { from recruited participants and encouraging staff } \\
\text { and peers at services is also effective as PWD } \\
\text { appreciate interpersonal channels of recruitment }\end{array}$ \\
\hline 11. & Preparation: & Provide multiple & Providing multiple methods of contact gives & Methods of contact relying on social media or new \\
\hline
\end{tabular}




\begin{tabular}{|c|c|c|c|c|}
\hline & $\begin{array}{l}\text { Research } \\
\text { stage }\end{array}$ & Recommendation & General rationale & Rationale for research with PWD \\
\hline & $\begin{array}{l}\text { Participant } \\
\text { recruitment }\end{array}$ & $\begin{array}{l}\text { methods of contact } \\
\text { when advertising the } \\
\text { study. }\end{array}$ & $\begin{array}{l}\text { potential participants flexibility in response } \\
\text { options. Methods of contact may include a } \\
\text { sign-up sheets, phone, text message } \\
\text { services, email, or social media such as } \\
\text { Facebook. }\end{array}$ & $\begin{array}{l}\text { technology may be less suitable/appealing for } \\
\text { PWD; reliance on only these methods may result } \\
\text { in sub-optimal and/or biased recruiting. The use of } \\
\text { dedicated social marketing campaigns may assist } \\
\text { with engagement (Gitlin et al). }\end{array}$ \\
\hline $1 \mathrm{~m}$ & $\begin{array}{l}\text { Preparation: } \\
\text { Participant } \\
\text { recruitment }\end{array}$ & $\begin{array}{l}\text { Provide clear and } \\
\text { detailed information } \\
\text { about the study in } \\
\text { recruitment material. }\end{array}$ & $\begin{array}{l}\text { Providing participants with transparent and } \\
\text { detailed information about the study during } \\
\text { recruitment may facilitate interest from } \\
\text { potential participants and also meet ethical } \\
\text { requirements. Relevant information may } \\
\text { include study aims, participant } \\
\text { requirements, study timeframe (e.g., } \\
\text { recruitment cut-off, data collection phases), } \\
\text { and expected benefits of research. }\end{array}$ & $\begin{array}{l}\text { Having limited information about the research may } \\
\text { be a barrier for PWD and their carers participating } \\
\text { in research (Connell et al., 2001; Garand et al., } \\
2009 \text { ). } \\
\text { If detailed information is required in information } \\
\text { sheets, present in a clearly structured format (e.g., } \\
\text { bullet points) to facilitate interpretation by PWD. }\end{array}$ \\
\hline $1 \mathrm{n}$ & $\begin{array}{l}\text { Preparation: } \\
\text { Participant } \\
\text { recruitment }\end{array}$ & $\begin{array}{l}\text { Provide a personal } \\
\text { face to the project } \\
\text { through face to face } \\
\text { presentations to } \\
\text { community } \\
\text { forums/groups }\end{array}$ & $\begin{array}{l}\text { Presentations given by members of the } \\
\text { research team to community audiences } \\
\text { increases the personal face of the project } \\
\text { and can promote an increased response as } \\
\text { people 'know' who is trying to recruit them. }\end{array}$ & $\begin{array}{l}\text { Holding community information sessions about the } \\
\text { research is a useful strategy for encouraging } \\
\text { research participating with this population (Author, } \\
2015 a \text { ) as it promotes familiarity with the research } \\
\text { team. }\end{array}$ \\
\hline 10. & $\begin{array}{l}\text { Preparation: } \\
\text { Participant } \\
\text { recruitment }\end{array}$ & $\begin{array}{l}\text { Include information } \\
\text { about the expected } \\
\text { positive outcomes of } \\
\text { being involved in the } \\
\text { study. }\end{array}$ & $\begin{array}{l}\text { Being involved in in-depth interviews can } \\
\text { be a rewarding and enriching experience for } \\
\text { participants (Dickson-Swift, et al., } 2007 \text {, } \\
\text { 2008). Sharing this information with } \\
\text { potential participants may increase their } \\
\text { interest in being involved in the study. } \\
\text { The broader community benefit of the } \\
\text { project should also be promoted. }\end{array}$ & $\begin{array}{l}\text { A significant barrier for PWD participating in } \\
\text { research is the perception of limited benefit of } \\
\text { doing so (Garand et al., 2009). } \\
\text { The positive outcomes of being involved in in- } \\
\text { depth interviews for PWD may include having an } \\
\text { opportunity to discuss issues important to them, } \\
\text { and having a sense of purpose by contributing to } \\
\text { the scientific literature and potentially improving } \\
\text { the quality of life of PWD) (Beard \& Fox, } 2008 \text {; } \\
\text { Garand et al., 2009; Gillies, 2000). } \\
\text { Including positive information in recruitment } \\
\text { materials may also involve using images and } \\
\text { language that portrays positive lived experiences } \\
\text { of PWD (Garand et al., 2009). }\end{array}$ \\
\hline $1 \mathrm{p}$. & Preparation: & Organise a face-to- & A preliminary meeting is useful for & PWD may appreciate meeting the researcher prior \\
\hline
\end{tabular}




\begin{tabular}{|c|c|c|c|c|}
\hline & $\begin{array}{l}\text { Research } \\
\text { stage }\end{array}$ & Recommendation & General rationale & Rationale for research with PWD \\
\hline & $\begin{array}{l}\text { voluntary } \\
\text { assent/consent }\end{array}$ & $\begin{array}{l}\text { face 'preliminary } \\
\text { meeting' with } \\
\text { potential participants }\end{array}$ & $\begin{array}{l}\text { requirements of participants (e.g., time } \\
\text { commitment). It is also useful for answering } \\
\text { participant questions and ensuring that } \\
\text { research eligibility criteria are satisfied. }\end{array}$ & $\begin{array}{l}\text { to the interview to promote familiarity and build } \\
\text { rapport (Cotrell \& Schulz, 1993; Dalby et al., } \\
\text { 2011; Dewing, 2002). } \\
\text { During this meeting explore what terminology they } \\
\text { use to refer dementia (e.g., memory problem, } \\
\text { Alzheimer's, and so forth.); and check they have } \\
\text { the capacity required to participant in the interview } \\
\text { (Clare, 2002; Garand et al., 2009; Gillies, } 2000 \text { ). } \\
\text { Providing participants with a list of topics to be } \\
\text { discussed in the interview can be helpful to allow } \\
\text { participants to prepare. }\end{array}$ \\
\hline $1 \mathrm{q}$. & $\begin{array}{l}\text { Preparation: } \\
\text { Obtaining } \\
\text { informed and } \\
\text { voluntary } \\
\text { assent/consent }\end{array}$ & $\begin{array}{l}\text { Obtain informed } \\
\text { assent from } \\
\text { participants who are } \\
\text { unable to provide } \\
\text { formal consent. }\end{array}$ & $\begin{array}{l}\text { While written assent from research } \\
\text { participants deemed not competent may not } \\
\text { be necessary to fulfil legal requirements of } \\
\text { research, its inclusion is important to ensure } \\
\text { all participants are voluntarily participating } \\
\text { in the study and to promote a person-centred } \\
\text { and inclusive approach. }\end{array}$ & $\begin{array}{l}\text { When developing assent forms for PWD it may be } \\
\text { useful to tailor them to include large printed text, } \\
\text { appropriate language, and a 'checklist' format so } \\
\text { important information is clearly outlined (Garand } \\
\text { et al., 2009; Gillies, 2000). Allowing PWD time to } \\
\text { review the material at their own pace is } \\
\text { recommended (Garand et al., 2009). Additionally, } \\
\text { having the option of writing initials or providing } \\
\text { verbal assent is important for those who find } \\
\text { writing difficult (Bamford \& Bruce, 2000; Gillies, } \\
\text { 2000). }\end{array}$ \\
\hline $1 \mathrm{r}$. & $\begin{array}{l}\text { Preparation: } \\
\text { Obtaining } \\
\text { informed and } \\
\text { voluntary } \\
\text { assent/consent }\end{array}$ & $\begin{array}{l}\text { Remind participants } \\
\text { of the research aims } \\
\text { and participant } \\
\text { commitments at each } \\
\text { contact. }\end{array}$ & $\begin{array}{l}\text { Discussing research aims and participant } \\
\text { commitments regularly facilitates informed } \\
\text { and voluntary assent/consent (van den } \\
\text { Hoonaard, 2002). }\end{array}$ & $\begin{array}{l}\text { Researchers should pay attention to verbal, non- } \\
\text { verbal, and behavioural indicators that suggests } \\
\text { that the PWD is wanting to participant in the } \\
\text { research (Dewing, 2002; Graneheim \& Jansson, } \\
\text { 2006; Hubbard et al., 2003; Slaughter et al., 2007) }\end{array}$ \\
\hline $1 \mathrm{~s}$. & $\begin{array}{l}\text { Preparation: } \\
\text { Obtaining } \\
\text { informed and } \\
\text { voluntary }\end{array}$ & $\begin{array}{l}\text { When conducting } \\
\text { research with dyads } \\
\text { clearly outline } \\
\text { confidentiality }\end{array}$ & $\begin{array}{l}\text { Clearly outlining confidentiality issues } \\
\text { ensures participants are aware that } \\
\text { information provided during interviews will } \\
\text { not be shared with other participants. This } \\
\text { awareness may encourage openness during } \\
\text { the interviews and prevent participants } \\
\text { asking about other participants' responses. }\end{array}$ & $\begin{array}{l}\text { Participants may feel reluctant to speak openly } \\
\text { about certain topics (e.g., the challenging aspects } \\
\text { of living with dementia) if they are uncertain } \\
\text { whether their interviews will be shared with the } \\
\text { other participant. Having said that, the option of } \\
\text { having a carer present for the interview may be } \\
\text { preferred by some PWD (Cotrell \& Schulz, 1993; } \\
\text { Dalby et al., 2011; Nygard, 2006). }\end{array}$ \\
\hline
\end{tabular}




\begin{tabular}{|c|c|c|c|c|}
\hline & $\begin{array}{l}\text { Research } \\
\text { stage }\end{array}$ & Recommendation & General rationale & Rationale for research with PWD \\
\hline $2 \mathrm{a}$. & $\begin{array}{l}\text { Appropriate } \\
\text { interview } \\
\text { settings }\end{array}$ & $\begin{array}{l}\text { an appropriate space } \\
\text { within an appropriate } \\
\text { setting }\end{array}$ & $\begin{array}{l}\text { Semi-structured interviews are often } \\
\text { conducted in a quiet room within participant } \\
\text { homes. Alternative venues should be } \\
\text { considered if there is no appropriate space } \\
\text { within the residence or if participants and/or } \\
\text { the researcher do not feel comfortable. } \\
\text { Suitable alternative venues may include a } \\
\text { quiet room in the researchers' workplace or } \\
\text { a bookable room in a community building, } \\
\text { such as a library. }\end{array}$ & $\begin{array}{l}\text { Conducting interviews in the homes of PWD is } \\
\text { common as it is convenient for participants (e.g., } \\
\text { some participants may not drive) and avoids } \\
\text { connotations of a clinical interview (Beard, 2004; } \\
\text { Cotrell \& Schulz, 1993; Garand et al., 2009; } \\
\text { Watchman \& Kerr, 2014). } \\
\text { However, some PWD consider their home to be a } \\
\text { private space or place of 'refuge' and opt for a } \\
\text { different location. The focus of the interview may } \\
\text { also dictate the interview setting (Blackman, et al., } \\
\text { 2003; Dewing, 2002; Olsson et al., 2013). For } \\
\text { example, if the focus of the research is about } \\
\text { involvement in the community, a suitable public } \\
\text { place may be the best setting. }\end{array}$ \\
\hline $2 b$. & $\begin{array}{l}\text { Data collection: } \\
\text { Appropriate } \\
\text { interview } \\
\text { settings }\end{array}$ & $\begin{array}{l}\text { Use environmental } \\
\text { cues to facilitate } \\
\text { discussion. }\end{array}$ & $\begin{array}{l}\text { Environmental cues can prompt or cue } \\
\text { recall issues relevant to the interview. } \\
\text { Furthermore, researchers may conduct a } \\
\text { 'walk-about' with the participant in a } \\
\text { particular environment to facilitate the } \\
\text { interview. }\end{array}$ & $\begin{array}{l}\text { Use of environmental cues to facilitate discussion } \\
\text { may be particularly helpful for PWD (Garand et } \\
\text { al., 2009). If environmental cues are not possible, } \\
\text { photos of relevant people, objects, or places may } \\
\text { help prompt discussion (Abbato, 2015; Dewing, } \\
\text { 2002; Watchman \& Kerr, 2014). }\end{array}$ \\
\hline 2c. & $\begin{array}{l}\text { Data collection: } \\
\text { Practicalities of } \\
\text { conducting } \\
\text { interviews }\end{array}$ & $\begin{array}{l}\text { Schedule interviews at } \\
\text { a preferred time for } \\
\text { participants. }\end{array}$ & $\begin{array}{l}\text { Participants are more likely to be engaged in } \\
\text { the interview process if it is conducted at a } \\
\text { time suitable for them. } \\
\text { To conduct interviews at appropriate } \\
\text { timeslots, researchers should be flexible, } \\
\text { such as conducting interviews outside of } \\
\text { business hours (such as on weekends). }\end{array}$ & $\begin{array}{l}\text { The engagement of PWD might be particularly } \\
\text { influenced by timing (Cotrell \& Schulz, 1993). } \\
\text { Contacting the PWD or their carer before the } \\
\text { interview is recommended (Cotrell \& Schulz, } \\
\text { 1993). Willingness to reschedule is important for } \\
\text { encouraging co-operation, preventing premature } \\
\text { termination of interviews, and improving the } \\
\text { quality of responses (e.g., minimise biased } \\
\text { responses or minimal elaboration; Cotrell \& } \\
\text { Schulz, 1993; Garand et al., 2009; Nygard, 2006). }\end{array}$ \\
\hline $2 \mathrm{~d}$. & $\begin{array}{l}\text { Data collection: } \\
\text { Practicalities of } \\
\text { conducting }\end{array}$ & $\begin{array}{l}\text { Take time to build } \\
\text { rapport with } \\
\text { participants. }\end{array}$ & $\begin{array}{l}\text { The importance of rapport building in } \\
\text { qualitative research is well established } \\
\text { (Brinkmann, 2007; Lavis, 2010; van den } \\
\text { Hoonaard, 2002). However, in building } \\
\text { rapport it is important to not just 'do' }\end{array}$ & $\begin{array}{l}\text { Rapport building is essential in this research area } \\
\text { given the highly personal nature of research topics } \\
\text { (Cotrell \& Schulz, 1993) and potential for } \\
\text { participants with dementia to provide researchers } \\
\text { with information they assume they want to hear }\end{array}$ \\
\hline
\end{tabular}




\begin{tabular}{|c|c|c|c|c|}
\hline & $\begin{array}{l}\text { Research } \\
\text { stage }\end{array}$ & Recommendation & General rationale & Rationale for research with PWD \\
\hline & & & $\begin{array}{l}\text { rapport, where the researcher engages in } \\
\text { 'faking friendship' to obtain knowledge } \\
\text { from the participant (Brinkmann, 2007). }\end{array}$ & $\begin{array}{l}\text { (Bond \& Corner, 2001) . Rapport with PWD } \\
\text { includes showing a genuine interest in their } \\
\text { experiences, having an open attitude, and } \\
\text { regarding the PWD as the expert on the interview } \\
\text { topic. } \\
\text { Some studies recommend having multiple } \\
\text { interviews with PWD to increase rapport (Clare et } \\
\text { al., 2008; Graneheim \& Jansson, 2006; Lloyd et } \\
\text { al., 2006)). }\end{array}$ \\
\hline $2 \mathrm{e}$. & $\begin{array}{l}\text { Data collection: } \\
\text { Practicalities of } \\
\text { conducting } \\
\text { interviews }\end{array}$ & $\begin{array}{l}\text { Be aware of your rate } \\
\text { of speech when } \\
\text { asking interview } \\
\text { questions. }\end{array}$ & $\begin{array}{l}\text { Asking interview questions in a measured, } \\
\text { slow pace facilitates accurate interpretation. }\end{array}$ & $\begin{array}{l}\text { Slowed speech suits the processing style of PWD } \\
\text { (Harman \& Clare, 2006; Moore \& Hollett, 2003; } \\
\text { Nygard, 2006). PWD might require longer time to } \\
\text { answer questions and researchers should allow } \\
\text { time for them to respond (Garand et al., 2009; } \\
\text { Hubbard et al., 2003). }\end{array}$ \\
\hline $3 a$. & $\begin{array}{l}\text { Data analysis: } \\
\text { Accurate } \\
\text { analysis and } \\
\text { interpretation } \\
\text { of data }\end{array}$ & $\begin{array}{l}\text { Attend to issues that } \\
\text { participants do not } \\
\text { discuss. }\end{array}$ & $\begin{array}{l}\text { There is a focus on what participants say } \\
\text { in in-depth interviews. However, it is also } \\
\text { important to reflect on issues not } \\
\text { discussed. }\end{array}$ & $\begin{array}{l}\text { Participants may find it difficult or even taboo to } \\
\text { discuss the challenges of living with dementia, } \\
\text { thus potentially presenting a biased perspective of } \\
\text { their lived experience (Cotrell \& Schulz, 1993). }\end{array}$ \\
\hline $3 \mathrm{~b}$. & $\begin{array}{l}\text { Data analysis: } \\
\text { Accurate } \\
\text { analysis and } \\
\text { interpretation } \\
\text { of data }\end{array}$ & $\begin{array}{l}\text { Have multiple } \\
\text { researchers code the } \\
\text { data. }\end{array}$ & $\begin{array}{l}\text { The credibility of interview data analysis is } \\
\text { improved with multiple researchers coding } \\
\text { the data (Braun \& Clarke, 2006). The } \\
\text { process of coding with multiple researchers } \\
\text { includes a primary researcher conducting, } \\
\text { transcribing, and analysing the data, while } \\
\text { other members of the research team read, } \\
\text { and independently code the data for } \\
\text { comparison (Braun \& Clarke, 2006). }\end{array}$ & $\begin{array}{l}\text { Multiple coders are important when conducting } \\
\text { research with PWD because it is common for } \\
\text { researchers in this field to have strong connections } \\
\text { and investment with the research topic (Garand et } \\
\text { al., 2009; Moore \& Hollett, 2003) which could } \\
\text { interfere with objective data analysis. It is } \\
\text { important that researchers are aware of their } \\
\text { potential for bias (Brinkmann, 2007; van den } \\
\text { Hoonaard, 2002). }\end{array}$ \\
\hline $3 \mathrm{c}$. & $\begin{array}{l}\text { Data analysis: } \\
\text { Involving } \\
\text { participants in } \\
\text { data analysis }\end{array}$ & $\begin{array}{l}\text { Include participants in } \\
\text { data analysis. }\end{array}$ & $\begin{array}{l}\text { Including participants in data analysis } \\
\text { facilitates the credibility and trustworthiness } \\
\text { of qualitative research. Involvement might } \\
\text { include encouraging participants to } \\
\text { brainstorm themes emerging from their } \\
\text { interviews, and/or inviting participants to }\end{array}$ & $\begin{array}{l}\text { Studies involving participants with dementia in } \\
\text { data analysis processes have indicated those with } \\
\text { mild impairments are able to be involved in this } \\
\text { process (Caddell \& Claire, 2002; Clare, 2002). } \\
\text { Furthermore, Clare (2002) reported that many } \\
\text { PWD found this process to be meaningful and }\end{array}$ \\
\hline
\end{tabular}




\begin{tabular}{|c|c|c|c|c|}
\hline & $\begin{array}{l}\text { Research } \\
\text { stage }\end{array}$ & Recommendation & General rationale & Rationale for research with PWD \\
\hline & & & $\begin{array}{l}\text { read drafts of reports in order to provide } \\
\text { feedback. }\end{array}$ & rewarding. \\
\hline $4 a$. & $\begin{array}{l}\text { Dissemination } \\
\text { of findings: } \\
\text { Providing } \\
\text { feedback to } \\
\text { participants }\end{array}$ & $\begin{array}{l}\text { Provide participants } \\
\text { with written feedback } \\
\text { about the study's } \\
\text { findings. }\end{array}$ & $\begin{array}{l}\text { Information sheets are an appropriate } \\
\text { method for providing feedback to } \\
\text { participants because they provide a succinct } \\
\text { outline of information, they are a tangible } \\
\text { resource for participants to refer to, and they } \\
\text { are economical and practical. }\end{array}$ & $\begin{array}{l}\text { Information sheets for PWD should have a } \\
\text { structured format (i.e., headings, bullet points.) } \\
\text { (Garand et al., 2009; Gillies, 2000) and be } \\
\text { presented in an appropriately 'simplified' manner } \\
\text { and/or summarise findings in tables and diagrams } \\
\text { to cater for cognitive and physical impairments } \\
\text { (e.g., visual deficits) associated with the condition. }\end{array}$ \\
\hline 4b. & $\begin{array}{l}\text { Dissemination } \\
\text { of findings: } \\
\text { Providing } \\
\text { feedback to } \\
\text { participants }\end{array}$ & $\begin{array}{l}\text { Provide participants } \\
\text { with the opportunity } \\
\text { to come to a group } \\
\text { feedback session. }\end{array}$ & $\begin{array}{l}\text { Group feedback sessions are useful for } \\
\text { conveying in-depth findings and providing } \\
\text { participants with an opportunity for } \\
\text { questions and comments. }\end{array}$ & $\begin{array}{l}\text { Group feedback sessions give opportunity for } \\
\text { participants to interact with other PWD. }\end{array}$ \\
\hline 4c. & $\begin{array}{l}\text { Dissemination } \\
\text { of findings: } \\
\text { Providing } \\
\text { feedback to } \\
\text { participants }\end{array}$ & $\begin{array}{l}\text { Reflect on the impact } \\
\text { of being involved in } \\
\text { the study with } \\
\text { participants. }\end{array}$ & $\begin{array}{l}\text { Reflections from the research team might } \\
\text { include professional and/or personal } \\
\text { insights, and challenges and rewards of } \\
\text { conducting the research. Additionally, } \\
\text { reflections from the research team } \\
\text { acknowledge the significance of participants } \\
\text { sharing their experiences for the research. }\end{array}$ & $\begin{array}{l}\text { Interview research investigating the experiences of } \\
\text { PWD may involve highly personal experiences, } \\
\text { meaning that the reflections from the research team } \\
\text { about their experiences of being involved in the } \\
\text { research might be particularly warranted. }\end{array}$ \\
\hline $4 \mathrm{~d}$. & $\begin{array}{l}\text { Dissemination } \\
\text { of findings: } \\
\text { Effective } \\
\text { communication } \\
\text { of research } \\
\text { findings }\end{array}$ & $\begin{array}{l}\text { Share research } \\
\text { findings with } \\
\text { community members } \\
\text { and groups. }\end{array}$ & $\begin{array}{l}\text { Academic journals and conferences have } \\
\text { their place in disseminating research } \\
\text { findings; however, it could be efficacious } \\
\text { to pursue other avenues when } \\
\text { disseminating findings via other methods } \\
\text { such as community forums, radio, } \\
\text { newspaper, and television. }\end{array}$ & $\begin{array}{l}\text { Relevant community groups for research focusing } \\
\text { on PWD include dementia and aged care services, } \\
\text { community social groups, retirement homes, and } \\
\text { dementia research centres. } \\
\text { Policy makers might also be relevant to target. }\end{array}$ \\
\hline $4 \mathrm{e}$. & $\begin{array}{l}\text { Dissemination } \\
\text { of findings: } \\
\text { Effective } \\
\text { communication } \\
\text { of research } \\
\text { findings }\end{array}$ & $\begin{array}{l}\text { Consider target } \\
\text { audience when } \\
\text { choosing journals to } \\
\text { publish research } \\
\text { findings. }\end{array}$ & $\begin{array}{l}\text { Consider the intended target audience of the } \\
\text { research when choosing journals to publish } \\
\text { in rather than focusing on other research } \\
\text { criteria such as the prestige of the journal. }\end{array}$ & $\begin{array}{l}\text { Target audiences for research focusing on PWD } \\
\text { include PWD, carers, families, clinicians, health } \\
\text { practitioners, policymakers, and so forth. }\end{array}$ \\
\hline $5 \mathrm{a}$. & Researcher & Be involved in & Debriefing sessions help researchers reflect & Researchers should not underestimate the \\
\hline
\end{tabular}




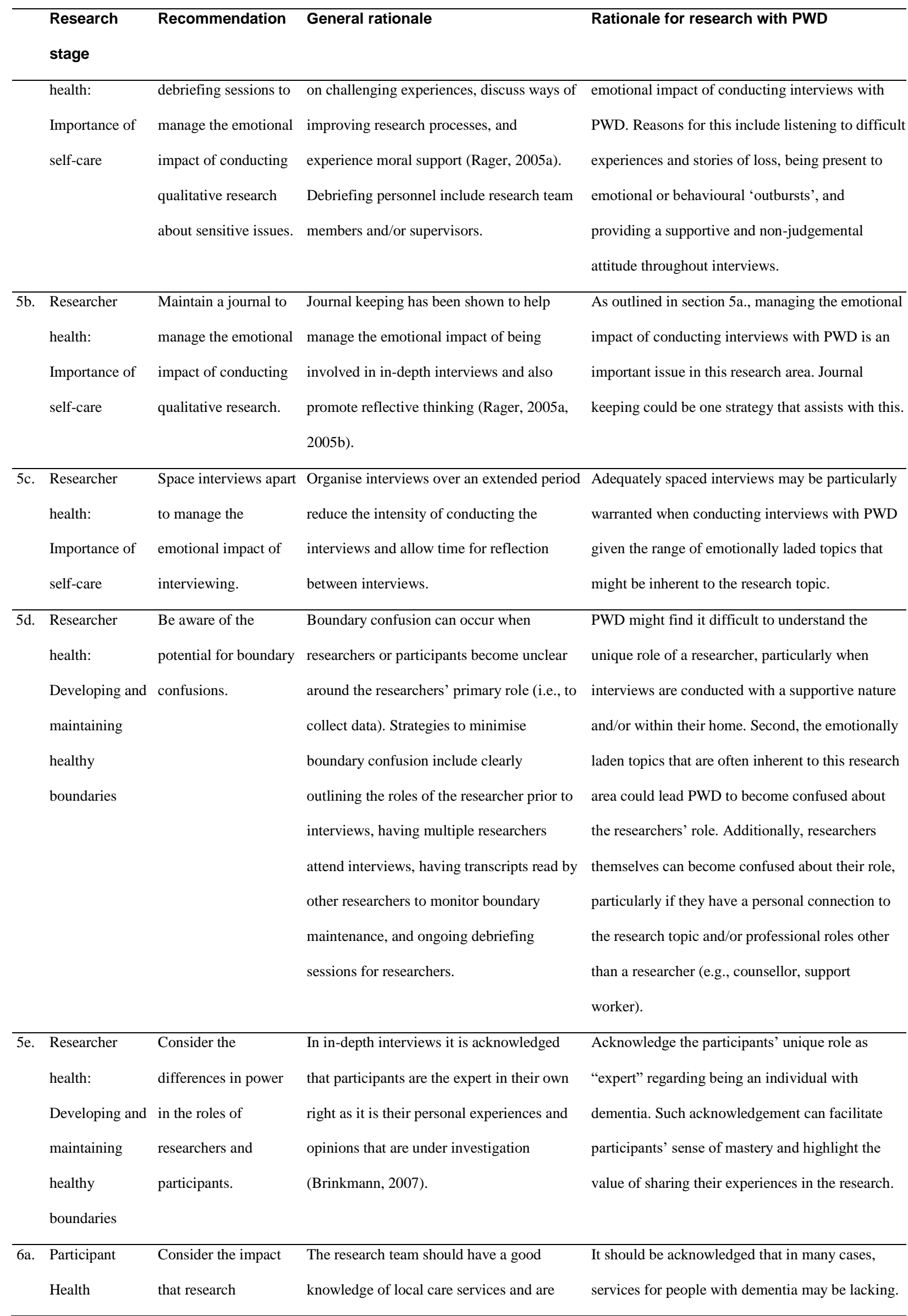




\begin{tabular}{llll}
\hline Research & Recommendation & General rationale & Rationale for research with PWD \\
\hline stage & & & \\
\hline & participation can have & able to provide information about these & Researchers should consider the extra \\
& on participant health & services required. & responsibility to advocate for improvement in \\
& & services for people where there research provides \\
& & evidence of unmet need. \\
\hline
\end{tabular}

\section{PWD = People with dementia}

